Section Editor

Mitchell S.V. Elkind, MD, MS

Jason Madey, MD

Rebecca K. Lehman, MD

Imran Chaudry, MD

Shannon L. Vaillancourt, CPNP

Correspondence \& reprint requests to S.L. Vaillancourt: vaillan@musc.edu

\title{
Teaching NeuroImages: \\ Atypical Wyburn-Mason syndrome
}

\section{Figure $1 \quad$ MRI}

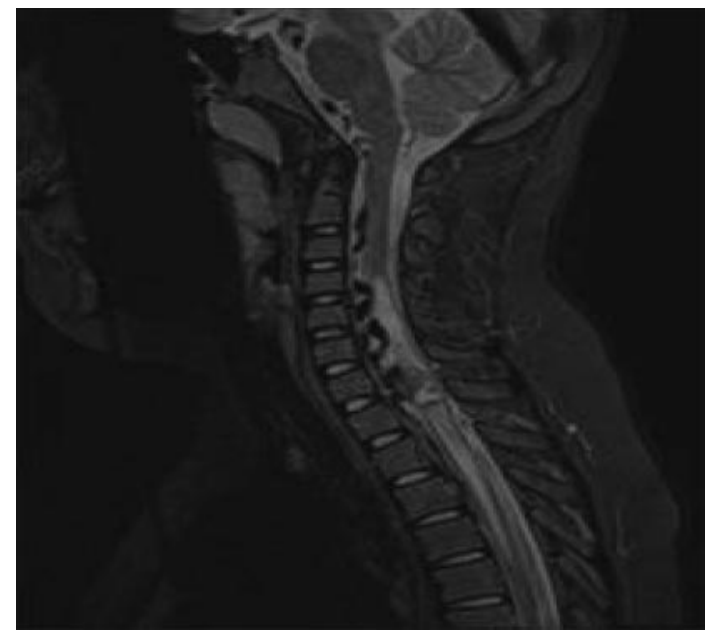

STIR fat-saturated T2-weighted sagittal MRI demonstrates cord expansion and edema (white signal from C4 to T4) secondary to spinal dural arteriovenous fistula. The serpiginous draining vein is seen anteriorly (black signal) extending cephalad.

A 10-year-old boy presented with sudden-onset left leg monoplegia. Imaging (figures 1 and 2) revealed complex vascular malformations involving the brain and spinal cord but ophthalmologic and skin examinations were normal. Wyburn-Mason syndrome is a rare phakomatosis characterized by unilateral arteriovenous malformations involving the retina, brain, and sometimes skin. ${ }^{1,2}$ We propose that Wyburn-Mason syndrome actually represents a continuous spectrum of disease, rather than a distinct syndrome, with some patients lacking the classic retinal and cutaneous findings. Even so, clinicians should be aware of the classic presentation and should assess any patient with a complex unilateral intracranial vascular malformation for retinal involvement.
Figure 2 Magnetic resonance angiography

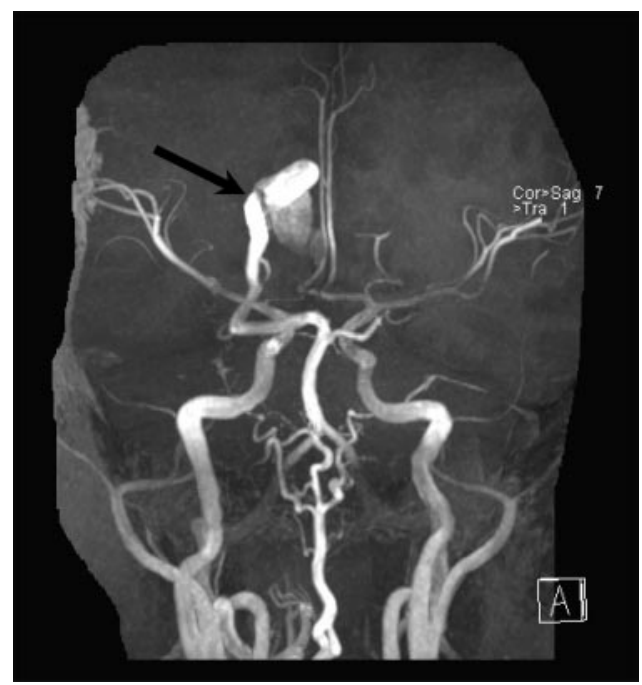

Three-dimensional time-of-flight magnetic resonance angiogram demonstrates arteriovenous fistula (arrow) between abnormally dilated right posterior cerebral artery and vein of Galen.

\section{AUTHOR CONTRIBUTIONS}

Drs. Madey, Lehman, and Chaudry and S. Vaillancourt have participated sufficiently in the work to take responsibility for content. All made substantial contributions. Dr. Jay Madey was responsible for drafting the original manuscript and was directly involved with the patient care, diagnosis, and management. Dr. Rebecca Lehman was responsible for revising the manuscript for content and was directly involved with the patient and involved in the interpretation and analysis of the data. Dr. Imran Chaudry contributed to the original manuscript by submitting figures as well the interpretation of the data. Shannon L. Vaillancourt was responsible to revision and submission of the manuscript and was directly involved with the management of the patient.

\section{REFERENCES}

1. Wyburn-Mason R. Arteriovenous aneurysm of midbrain and retina, facial naevi, and mental changes. Brain 1943; 66:163-203.

2. Lester J, Ruano-Calderon LA, Gonzalez-Olhovich I. Wyburn-Mason syndrome. J Neuroimaging 2005;15: $284-285$. 


\title{
Neurology
}

\author{
Teaching NeuroImages: Atypical Wyburn-Mason syndrome \\ Jason Madey, Rebecca K. Lehman, Imran Chaudry, et al. \\ Neurology 2012;79;e84 \\ DOI 10.1212/WNL.0b013e318268460f
}

This information is current as of September 3, 2012

Updated Information \&

Services

References

Subspecialty Collections

Permissions \& Licensing

Reprints including high resolution figures, can be found at:

http://n.neurology.org/content/79/10/e84.full

This article cites 2 articles, 0 of which you can access for free at: http://n.neurology.org/content/79/10/e84.full\#ref-list-1

This article, along with others on similar topics, appears in the following collection(s):

Arteriovenous malformation

http://n.neurology.org/cgi/collection/arteriovenous_malformation CT

http://n.neurology.org/cgi/collection/ct

MRI

http://n.neurology.org/cgi/collection/mri

Retina

http://n.neurology.org/cgi/collection/retina

Information about reproducing this article in parts (figures,tables) or in its entirety can be found online at:

http://www.neurology.org/about/about_the_journal\#permissions

Information about ordering reprints can be found online:

http://n.neurology.org/subscribers/advertise

Neurology ${ }^{\circledR}$ is the official journal of the American Academy of Neurology. Published continuously since 1951, it is now a weekly with 48 issues per year. Copyright Copyright (? 2012 by AAN Enterprises, Inc.. All rights reserved. Print ISSN: 0028-3878. Online ISSN: 1526-632X.

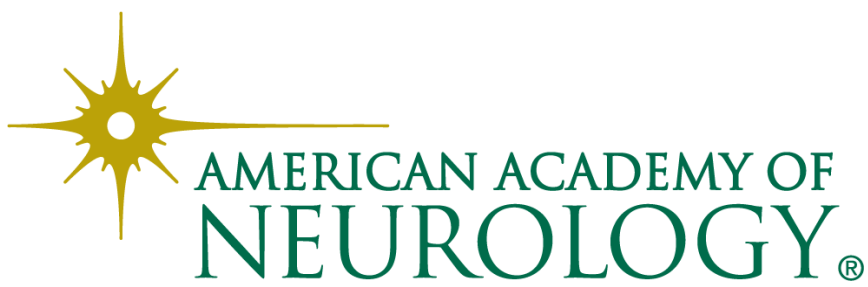

